\title{
Creating a Communicative Language Teaching Environment for Improving Students' Communicative Competence at EFL/EAP University Level
}

\author{
Muhammad U. Farooq ${ }^{1}$ \\ ${ }^{1}$ English Language Centre, Taif University, At-Taif, Kingdom of Saudi Arabia \\ Correspondence: Muhammad U. Farooq, English Language Centre, Taif University, PO Box 888, Taif University, \\ At-Taif, Kingdom of Saudi Arabia. Tel: 966-582-912-894. E-mail: umar.fui@gmail.com
}

Received: December 18, 2014 Accepted: January 5, 2015 Online Published: March 30, 2015

doi:10.5539/ies.v8n4p179

URL: http://dx.doi.org/10.5539/ies.v8n4p179

\begin{abstract}
The present research focuses on teachers' perceptions and practices regarding Communicative Language Teaching (CLT) and its impact on communicative competency of the students. A questionnaire was used to collect the quantitative data from teachers. The results show that the EFL teachers are aware of the CLT characteristics, its implementation and impact on the communicative competence of the students. The results suggest that despite showing keen interest in change and being eager to implement CLT, they are not optimistic about the complete adoption of CLT due to the problems and challenges they face in the classroom, like overcrowded classes, non-availability of AV aids, students' low level of proficiency, time constraints, etc. They believe that only by overcoming the difficulties, and by establishing more favourable conditions for the implementation of CLT, they can truly benefit from CLT in their classrooms.
\end{abstract}

Keywords: communicative approach, communicative competence

\section{Introduction}

In response to grammar translation method and audio-lingual method, the British linguists introduced Communicative language teaching (CLT) in 1960s which became a dominant language teaching approach in 1970s. Initially designed for ESL context, CLT was applied in English speaking countries where English teachers supported a skill-based, discovery-oriented, collaborative approach to education (Holliday, 1994). A number of CLT based language courses and textbooks were introduced in second language learning (L2) with an emphasis to improve communicative competence of the learners. The purpose of CLT was to provide the learners with opportunities to learn and use the target language in L2 context. Therefore, the focus in language teaching shifted from drill-based language activities to communicative-based activities to provide a natural growth of language ability. CLT refers to both processes and goals in classroom learning. Identification of learners' communicative needs provided a base for curriculum design (Van Ek, 1975). According to Mey (1998), the basic principles of CLT include learner-oriented classroom, opportunities to develop a wide repository of activities, multiple role of the teachers, and use of authentic materials.

The pivotal concept in CLT is communicative competence, a term introduced in the early 1970s in language education (Savignon, 1972; Hymes, 1971; Habermas, 1970; Jakobovits, 1970). Hymes (1971) coined the term 'Communicative Competence' in contrast to Chomsky's concept of communicative view of language and competence. Chomsky discusses that the focus of linguistic theory is to characterize the abstract abilities of a speaker which enable them to produce grammatically correct sentences in a language whereas Hymes argues that the linguistic theory needed to be seen as part of a more general theory incorporating communication and culture. In Hymes' view theory of communicative competence is a definition of what a speaker needs to know in order to be communicatively competent in a speech community. Hymes (1972, p. 281) argues that both knowledge of a language and ability to use it is the communicative competence in terms of its formality, feasibility, appropriateness, context, and performance of the language act. So this concept contracts with Chomsky's competence based on abstract grammatical knowledge. Communicative language teaching is defined as an approach to foreign or second language teaching which aims to develop communicative competence (Richards, J. Platt, \& H. Platt, 1992). 
Realizing the importance of English as a lingua franca and a language of science and technology for the last few years, the scenario of English language teaching and learning has been changing at an international level. In the Saudi Arabian context, English has been embraced as one of the key languages of the educational planning and now English has been made as a compulsory subject from elementary level to university level. The establishment of English language centres (ELCs) in the universities has played a fundamental role in initiating a positive academic shift towards learner-centered pedagogy instead of the traditional teacher-centered teaching methodology. Al-Abedalhaq and Samdi (1996) argue that Saudi students understand the significance of English in the modern era. But at the same time, in-house and international tests witnessed poor performance of Saudi students (Cambridge Examination Center, 2009; Educational Testing Services, 2003 to 2009). This situation arises many questions about teaching methodologies in practice in universities.

In the current context of study (i.e. a Saudi university), English for Academic Purposes (EAP) syllabus has been designed keeping in view student needs. However, the teachers face certain problems in executing the syllabus in its true sense. As observed at the ELC, Taif University, these problems include students' low proficiency in English language, lack of interest in learning English, over-crowded classes, lack of technological support, etc (Javid, Al-thubaiti, \& Uthman, 2013). This research focused on creating a better learning environment by designing CLT-based activities and involving students in the learning process.

\subsection{Research Questions}

1) What teaching approaches/methods are adopted by the English language teachers?

2) How do they perceive CLT in their classrooms?

3) How do they create a CLT environment in their classrooms?

4) What problems do they face in establishing a CLT environment in the classroom?

5) How can implementation of CLT improve communicative competence of the students?

\subsection{Review of Relevant Literature}

Language is viewed as a vehicle for communication and conveying knowledge. It involves two parts, e.g., a speaker and a listener, and a writer and a reader. It suggests three principals in language learning, according to Richards and Rodgers (2001), 'communication principle, task-based principle, and meaningfulness principle' (p. 161). When these principals are applied in a language learning environment, functional activities and social interaction activities take place (Littlewood, 1981). Consequently, it is related to how well students are engaged in learning and makes authentic use of language. According to Nunan (1991, p. 280) communicative approach characterizes five features which are emphasizing on learning to communicate; introducing authentic texts in learning environment, providing opportunities to focus on language and learning process, enhancing learner's own experiences in language learning, and linking classroom language learning experience with activities outside the classroom. Nunan's explanation of CLT suggests that any teaching practice that helps students develop their communicative competence in an authentic context is considered an effective instructional strategy in ESL/EFL situation. No matter how authentic the settings are, the learning or teaching takes place in a classroom which is far from being authentic. Teachers are supposed to create 'real settings' to provide the students with chances to perform real life acts. Due to the unpredictability of communication, 'real things' are unpredictable and thus can't be created either. In addition, communicative approach requires a teacher of exceptional abilities. He must know what the real settings are and how to perform in these settings himself. He must be technically skilled so as to ask down-to-earth questions (Medgyes, 1990).

According to Breen and Candlin (2001), in socio-cognitive aspect, knowledge and learning are social constructs and they are based on communication and it leases us to learner-centred and experience-based learning. In CLT, learning has become more learner-centred and less structurally driven" (Kern \& Warschauer, 2000, p. 5). Therefore, in CLT a learner is viewed as an active participant in the construction of knowledge, rather than passive recipients of information provided by the teacher or the textbook. On the other hand, a language teacher is no longer viewed as the authority of the knowledge, but as a facilitator, participant, and group manager (Richards \& Rodgers, 2001, p. 167) who could create a productive learning environment for the learners.

CLT stresses on both 'what to teach' and 'how to teach' and it focuses on the significance of language functions rather than depending solely on grammar and vocabulary. According to Richards (2006), language instruction and learning in the early decades of CLT focused on fluency and the integration of language skills, rewarding learners' efforts to speak or write even if errors resulted. Many kinds of instructional activities were recommended, from mechanical language practice involving the entire class or individuals, to much more open-ended communicative practice, some of it requiring either one-way or two-way exchange of information 
through activities in which partners need to share and consolidate information to carry out the task. However, now other types of activities such as inductive, discovery-oriented learning where students try to find patterns in language texts and datasets (e.g., common collocations of words, and guess their meanings or usage) are also encouraged. The teacher's role is to create a nurturing, collaborative learning community and worthwhile activities for students. Richards' own English language textbooks embody CLT principles as well (e.g., New Interchange, Richards, 1998; and Passages, Richards \& Sandy, 2008). The existence of a flexible curriculum over which the teacher and students have a fair amount of control and input, small class sizes, and relatively little formal assessment is assumed in much CLT pedagogy. In CLT, contextualization, meaning-making, and the usefulness of the language being learned and the activities being engaged in should be very evident in curriculum and instruction, keeping in mind that communication takes place in different ways, using different means. Learners are encouraged to do communicative activities which will polish their speaking, listening, writing, reading or even thinking in a natural way.

Savignon (2002) discusses that the "communicative competence" is the main theoretical concept in CLT. The term was introduced by Hymes in second/foreign language education in early 1970s. Competence means expression, interpretation, and negotiation of meaning. It also considers psycholinguistic and sociocultural perspectives in ESL/EFL environment.

The frequently discussed terms 'competence' and 'performance' in language teaching were introduced by Chomsky (1965). Competence refers to knowledge of grammar and of other aspects of language whereas performance refers to actual use. Chomsky (1965) claims that 'competence refers to the linguistic system (or grammar) that an ideal native speaker of a given language has internalized whereas performance mainly concerns the psychological factors that are involved in the perception and production of speech; e.g. perceptual parsing strategies, memory limitations, and the like. However, Hymes (1971) and Campbell and Wales (1970) considered that the competence-performance distinction provides no place for consideration of the appropriateness of sociocultural significance of an utterance in the situational and verbal context in which it is used. They came up with "a broader notion of competence and that is communicative competence which includes not only grammatical competence (or implicit and explicit knowledge of the rules of grammar) but also contextual or sociolinguistic competence (knowledge of the rules of language use)" (Canale \& Swain 1980, p. 1). The communicative competence leads to the integration of both grammatical competence and sociolinguistic competence in syllabus designing, teaching methodology and assessment (the actual demonstration of knowledge in real life situations and for authentic communication purposes (Allen, 1978; Candlin, 1978; Munby, 1978; Stern, 1978; Morrow, 1977; Wilkins, 1976).

Savignon (1983) proposed an 'inverted pyramid' classroom model to represent communicative competence that consists of grammatical competence, discourse competence, socio-cultural competence, and strategic competence. All the components are inter-linked and inter-dependent. 


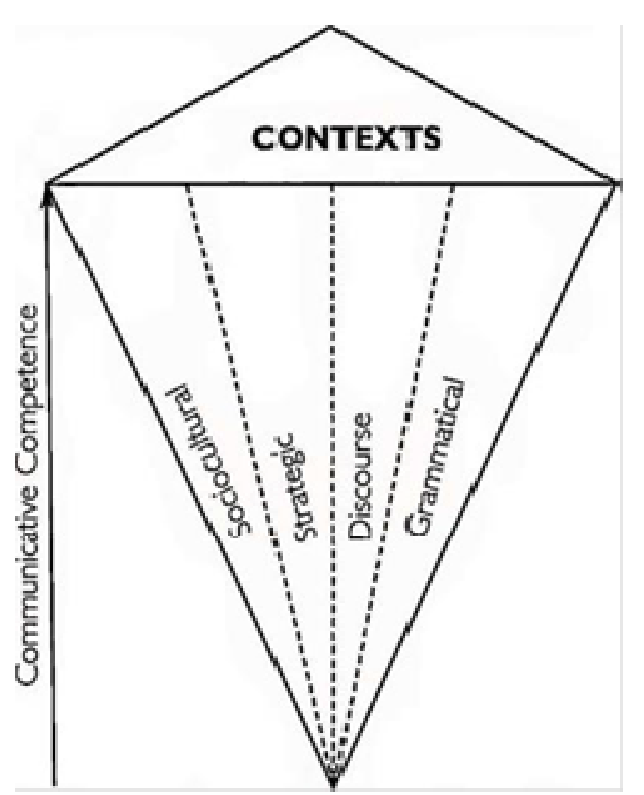

Figure 1. Communicative competence model (Savignon, 1983)

Grammatical competence, as explained by Savignon (1983), refers to sentence-level grammatical forms, the ability to recognize the lexical, morphological, syntactic, and phonological feature of a language and to make use of these features to interpret and form words and sentences. Discourse competence refers to isolated words or phrases and interconnectedness of a series of utterances, written words, and/or phrases to form a text, a meaningful whole. The text might be a poem, an e-mail message, a sportscast, a telephone conversation, or a novel. Strategic competence include coping techniques which we use in unfamiliar context, with constraints due to imperfect knowledge of rules or limiting factors in their application such as fatigue or distraction. Socio-cultural competence refers to the social rules of language use and it requires an understanding of the social context in which language is used: the roles of the participants, the information they share, and the function of the interaction. The learners improve their communicative competence through practice and experience in an increasingly wide range of communicative contexts and events.

There is a variety of activities to enhance communicative competence of the students in a CLT classroom. Such activities must encourage learners to interact meaningfully in the target language. According to Celce-Murcia (1991), these classroom activities can be grouped under four basic headings; structured activities (structured interview), performance activities (role play), participation activities (guided discussions), and observation activities (movies). Other CLT activities may include information gap activities, jigsaw activities, communication games, discussion and debates, and prepared talks and oral presentations.

CLT activities can also be classified as fluency and accuracy activities as one of the goals of CLT is to develop fluency in language use. Richards (2006) discusses that "fluency is the natural language use occurring when a speaker engages in meaningful interaction and maintains comprehensible and ongoing communication despite limitations in his or her communicative competence" (p.14). He highlights that activities focusing on fluency have features like natural use of language, communication, meaningful use of language, use of communicative strategies, producing language that may not be predictable, and seeking to link language use to context.

\subsubsection{Relevant Studies}

Wang (1990) conducted his research in a foreign language school in China and reported that CLT is contributing to the development of all language skills and there is a growing recognition among teachers and learners despite difficulties. He also reported that teachers have reported progress in teaching communicatively. Fang (1996) claimed that contextual factors including classroom conditions could have a powerful impact on teachers and might affect their classroom practice. Another study conducted in Korea by Li (1998) in Korea on the difficulties faced by English teachers in adopting CLT suggested that there was a need to change the traditional approach of teaching English as a second / foreign language. He argues that the teachers are facing problems in implementing CLT in their classrooms due to the predominance of text-centered and grammar-centered practices in Korea. Gorsuch's model (2000) also showed that school and classroom conditions influenced teachers' perceptions 
regarding the use of CLT. Taguchi (2002) found that even though high school teachers were still using exam-oriented teaching methodologies, they wanted to teach communicative skills. Gorsuch (2001) reported after conducting a research in Japanese high schools that teachers mildly approved of CLT activities, although there had to face difficulties and challenges in implementing CLT activities in their classrooms.

In a study conducted by Vasilopoulos (2008) writes that after many years of introducing CLT approach in Korea and despite curriculum reform and passage of time, many English teachers remained skeptical about the effectiveness of CLT in their language classrooms.

In China, CLT got recognition due to the government's educational policies with a special focus on increasing the students' communicative competence. Guangwei Hu (2005, p. 637), quoted by Wenjie (2009) says that "despite a lack of consensus among researchers regarding the appropriateness of CLT for China, the Ministry of Education was impressed by the high profile that the methodology enjoyed internationally and was convinced that it would provide the best solution for the wide spread problem of students' low competence in using English for communication even after years of formal instruction in the language".

Akram and Mehmood (2011, p. 175) conducted a research on introducing CLT in teacher training programs in Pakistan. They concluded that "CLT enhances the learners' confidence and it gives a sense of satisfaction to the teacher as well in the sense that $\mathrm{s} / \mathrm{he}$ is successful in making the students use the foreign language in their conversation. CLT gives clarity to the expression. Communicative approach is better than all the other methods of language teaching in general and Grammar Translation Method (GTM) in particular".

Wei (2011) opined that keeping view of the gap between CLT approach and challenges confronting EFL teaching and learning, most of the countries should carefully study their English teaching situations and decide how CLT can best serve their needs and interests of the students.

Research conducted so far in this context suggests that there is a growing approval of CLT use in EFL context. Though there is inconsistency between the teachers' beliefs and practices, their perceptions regarding the use of CLT is gradually changing.

\section{Method}

The present research is descriptive in nature but mixed-method approach was adopted. Creswell, Plano-Clark, Gutmann and Hanson (2003, p. 212) discuss mixed approach as a collection of qualitative and quantitative data in a research. It also helps the researcher to draw on various possibilities of collecting and analysing data (Tashakkori \& Teddlie, 1998) in a broad perspective (Creswell, 2003). Triangulation is another aspect of mixed method which validates and guarantees credibility of the findings.

Data was collected through qualitative and quantitative tools which were represented in a teacher questionnaire and classroom observation. As for the questionnaire, teachers were inquired about their perceptions regarding CLT, implementation and problems they face in the classroom while using CLT. Classroom observation was also made to get a real picture whether teachers themselves are interested in creating CLT environment. Students' involvement was also observed during the classroom observation in CLT tasks designed keeping in view the course description / outline and lesson plans.

The sample of study included 50 male and 50 female teachers at Taif University English Language Centre (TUELC) for questionnaire, whereas 10 classes (male teachers) were selected randomly and were observed for collecting the data.

\section{Results and Discussion}

The present study focuses on teachers' perception regarding creating a CLT environment for improving students' communicative competence at TUELC. The objectives of the research were to find out the teachers' perceptions regarding CLT in their classroom, to observe whether CLT improves students' communicative competence and EFL learning in Saudi universities, and to suggest measures regarding creating a CLT environment in the classroom.

\subsection{Teachers' Questionnaire}

The questionnaire consisted of four parts; seeking teachers' opinion regarding their favorite teaching method(s), perception regarding CLT, role of a teacher in a CLT classroom, and how CLT activities affect students' communicative competence.

\subsubsection{Teaching Methods}

The teachers were asked about the teaching method they usually use in their ELT classroom. The methods included 
audio-lingual, grammar translation, communicative approach, direct method, natural approach, silent way and total physical response.

Table 1. Teaching methods

\begin{tabular}{|c|c|c|c|c|c|c|c|c|c|c|c|}
\hline No. & Statements & $\mathrm{Aly}$ & ays & $\mathrm{Oft}$ & & & times & Ra1 & & $\mathrm{Ne}$ & \\
\hline & & $\mathrm{M}$ & $\mathrm{F}$ & $\mathrm{M}$ & $\mathrm{F}$ & $\mathrm{M}$ & $\mathrm{F}$ & $\mathrm{M}$ & $\mathrm{F}$ & $\mathrm{M}$ & $\mathrm{F}$ \\
\hline 1 & Audio-lingual method & 16 & 14 & 50 & 60 & 34 & 26 & 0 & 0 & 0 & 0 \\
\hline 2 & Grammar translation & 12 & 0 & 32 & 08 & 30 & 36 & 26 & 10 & 0 & 46 \\
\hline 3 & Communicative approach & 26 & 48 & 66 & 38 & 8 & 8 & 0 & 6 & 0 & 0 \\
\hline 4 & Direct method & 34 & 10 & 30 & 42 & 36 & 18 & 0 & 26 & 0 & 4 \\
\hline 5 & Natural approach & 12 & 6 & 44 & 36 & 30 & 44 & 14 & 10 & 0 & 4 \\
\hline 6 & Silent way & 14 & 0 & 32 & 8 & 10 & 42 & 12 & 40 & 32 & 10 \\
\hline 7 & Total physical response & 20 & 10 & 48 & 40 & 18 & 32 & 6 & 18 & 8 & 0 \\
\hline
\end{tabular}

A teacher may restrict himself to a specific method/approach or he may adopt a variety of teaching methodologies/approaches according to the situation. In Saudi Arabian context, English language is a compulsory subject at school and university levels and activity based syllabuses have been introduced to make the students proficient in English language skills.

The data show that the majority of the teachers favoured (always and often) communicative approach ( $89 \%)$, direct method (76\%), and audio-lingual method (70\%) collectively. However, looking at 'always' only, majority of the female teacher opted for communicative approach (48\%) while male teachers were in favour of direct method $(34 \%)$ in their classes. Interestingly, $12 \%$ male teachers selected grammar translation, whereas none of the female teachers opted for it. The present data analysis reflected that female teachers were more aware of the CLT approach as $48 \%$ of them always used CLT in their classroom as compared to $26 \%$ of male colleagues.

To motivate the students, as the data collected through a teachers' questionnaire reflected, they opted for a variety of methodologies / approaches in their classrooms including communicative approach at the top. In the context of modern teaching, conceptual strategies are always needed to deal with the day to day teaching / learning situations in which the learners face difficulties, and without some strategies they perhaps can't achieve the target (Khan, 2011). To make their teaching more effective, they apply other methodologies as well which include direct method, audio-lingual method and total physical response keeping in view the their teaching situation.

\subsubsection{Perceptions Regarding CLT}

In the second part of the questionnaires, teachers' perceptions were sought regarding CLT's characteristics in a language classroom.

Table 2. Teachers' perception regarding CLT

\begin{tabular}{llllllllll}
\hline & Statements & Yes & & No & \multicolumn{3}{c}{ Not sure } \\
\hline & & $\mathrm{M}$ & $\mathrm{F}$ & $\mathrm{M}$ & $\mathrm{F}$ & $\mathrm{M}$ & $\mathrm{F}$ \\
\cline { 2 - 9 } 1. & Focuses on learner-centred approach & 80 & 90 & 6 & 0 & 14 & 10 \\
2. & Emphasises fluency over accuracy & 74 & 90 & 22 & 0 & 4 & 10 \\
3. & Relies heavily on listening and speaking skills & 88 & 64 & 6 & 36 & 6 & 0 \\
4. & Gives less importance to reading and writing & 56 & 10 & 48 & 54 & 6 & 36 \\
5. & Neglects grammar teaching. & 50 & 8 & 42 & 76 & 8 & 16 \\
6. & Emphasises communication in classroom. & 96 & 100 & 6 & 0 & 0 & 0 \\
7. & Requires a high proficient teacher. & 86 & 70 & 4 & 14 & 10 & 16 \\
8. & Demands only English in the classroom & 92 & 92 & 8 & 8 & 0 & 0 \\
\hline
\end{tabular}




\begin{tabular}{llllllll}
\hline 9. & Involves group work or pair work. & 94 & 100 & 0 & 0 & 4 & 0 \\
10. & Requires higher knowledge of culture of the target language. & 90 & 74 & 10 & 8 & 0 & 18 \\
\hline
\end{tabular}

Most of the respondents were confident regarding CLT as it emphasizes communication in classroom (98\%), involves group or pair work (97\%), demands only English in the classroom (92\%), and focuses on learner-centred approach (85\%). In the same vein, the goal of language teaching is to develop communicative competence (Richard \& Rodger, 1999, p. 69). Communicative competence includes grammatical competence, discourse competence, sociolinguistic competence, and strategic competence. Communicative language abilities include knowledge or competence and proficiency in the application of the competence in the communicative use of language. The present study results reported that though the teachers tend to combine various teaching methodologies in their classroom, they are well-aware of the CLT characteristics. However, their priorities as reflected in the questionnaire may have been influenced by the local context and changing scenario of teaching/learning English in Saudi Arabia or non-English speaking countries.

On the other hand, results show that there was difference of opinion between male and female teachers regarding the teaching of grammar in a CLT classroom. In terms of negligence of teaching grammar in CLT classroom, 50\% male teachers were in favour of the statement that CLT neglects grammar teaching, while $76 \%$ female teachers were against the statement which means that majority of the female teachers think that grammar teaching is not neglected in a CLT classroom. In CLT, wherever possible, learners are first exposed to a new language in a comprehensible context, so that they are able to understand its function and meaning.

In response to the statement that CLT relies heavily on listening and speaking skills, majority of the teachers ( $88 \%$ male and $64 \%$ female) agreed to the statement, but a good number of female teachers (36\%) were against the statement. As far as the teaching of reading and writing is concerned, there was a divided response from both genders. Majority of the male teachers (56\%) were positive with the view that less importance is given to reading and writing, whereas $48 \%$ do not think so. On the other hand, majority of female teachers (54\%) didn't favour the statement and $36 \%$ of them were not sure about the statement. Such results may convey a sense that there is another misconception that CLT means teaching only speaking. CLT focuses on communication, both writing and speaking, involving two persons. While reading a text, a reader interacts with the writer and derives meanings just like talking to someone. A glance at the recent CLT based textbooks reflects spoken and written communication in different contexts. This situation also reflects a paradigm shift in CLT that initially focused on oral skills mainly but later on, reading, writing and grammar are being given equal importance in a CLT-classroom to equip the students with fluency and accuracy in all the four skills and grammar as well.

3.1.3 An English Teacher in a CLT Classroom Should ...

The third part of the teachers' questionnaire discusses the role of a teacher in a CLT classroom.

Table 3. Role of a teacher in a CLT classroom

\begin{tabular}{llllllllllll}
\hline \multirow{2}{*}{ Statements } & \multicolumn{2}{l}{ Strongly Agree } & \multicolumn{2}{l}{ Agree } & \multicolumn{3}{l}{ Not Sure } & \multicolumn{2}{c}{ Disagree } & \multicolumn{2}{l}{ Strongly Disagree } \\
\hline & $\mathrm{M}$ & $\mathrm{F}$ & $\mathrm{M}$ & $\mathrm{F}$ & $\mathrm{M}$ & $\mathrm{F}$ & $\mathrm{M}$ & $\mathrm{F}$ & $\mathrm{M}$ & $\mathrm{F}$ \\
\cline { 2 - 11 } 1. & be a native speaker & 14 & 0 & 12 & 8 & 14 & 18 & 50 & 48 & 10 & 26 \\
2. & have native-like pronunciation & 30 & 0 & 36 & 50 & 14 & 24 & 20 & 26 & 0 & 0 \\
3. & have native-like fluency & 22 & 32 & 46 & 44 & 16 & 10 & 16 & 14 & 0 & 0 \\
4. & have native-like accuracy & 30 & 30 & 40 & 52 & 14 & 10 & 16 & 8 & 0 & 0 \\
5. & provide materials & 22 & 54 & 70 & 46 & 2 & 0 & 6 & 0 & 0 & 0 \\
6. & be a facilitator & 28 & 64 & 58 & 36 & 12 & 0 & 2 & 0 & 0 & 0 \\
7. & be a communication model & 34 & 72 & 54 & 28 & 8 & 0 & 4 & 0 & 0 & 0 \\
8. & be a communicator & 24 & 78 & 60 & 22 & 14 & 0 & 2 & 0 & 0 & 0 \\
\hline
\end{tabular}

A teacher has two important roles in a CLT classroom. Firstly, he is supposed to facilitate the communication process among the students in the classroom and between the students and text and various activities. Secondly, act as an independent participant within the group of students. So, a teacher has to act like an organizer of 
resources and as a resource himself, and at the same time, as a guide within the classroom procedures and activities.

In the present research, majority of the teachers favoured (strongly agreed and agreed) the role of a teacher in CLT classroom as a communication model (94\%), a facilitator (93\%), and a communicator (92\%). He provides materials (96\%). According to Xia (2010) "the role of the teacher is not only that of a resource and lecturer but also a facilitator, an organizer, a guide and more important a creator of environment in which learners learn how to learn" (p. 20).

The respondents opined that a teacher must have native like accuracy (76\%) and fluency (72\%). Also, (67\%) of respondents disagreed that in a CLT-classroom there should be a native speaker but they agreed to the statement that a teacher must have native-like pronunciation (58\%). To justify his roles, a teacher is required to reach a benchmark of English proficiency to express his knowledge and knows how to teach it, helping his learners to use the target language for communication. For this reason, "in recent years, concern about the subject matter knowledge of L2 teachers, both NS (native-speaker) and NNS (non-native speaker), has grown, especially in relation to the teaching of English" (Andrews, 2003, p. 82).

\subsubsection{How Does CLT Impact Students' Communicative Competence in Classroom?}

The fourth part of the questionnaire aimed at finding out how CLT impacts communicative competence of the students.

Table 4. Impact of CLT on students' communicative competence

\begin{tabular}{lccccccccccc}
\hline Statements & \multicolumn{1}{c}{ Strongly Agree } & \multicolumn{2}{c}{ Agree } & \multicolumn{2}{c}{ Not Sure } & \multicolumn{2}{c}{ Disagree } & \multicolumn{2}{c}{ Strongly Disagree } \\
\hline & $\mathrm{M}$ & $\mathrm{F}$ & $\mathrm{M}$ & $\mathrm{F}$ & $\mathrm{M}$ & $\mathrm{F}$ & $\mathrm{M}$ & $\mathrm{F}$ & $\mathrm{M}$ & $\mathrm{F}$ \\
\hline talk like a native speaker & 10 & 20 & 64 & 28 & 18 & 30 & 8 & 18 & 0 & 4 \\
acquire native-like pronunciation & 18 & 28 & 44 & 10 & 32 & 28 & 6 & 34 & 0 & 0 \\
acquire native-like fluency & 16 & 30 & 64 & 40 & 14 & 20 & 6 & 10 & 0 & 0 \\
acquire native-like accuracy & 16 & 28 & 60 & 40 & 16 & 22 & 8 & 10 & 0 & 0 \\
communicate effectively in L2 & 24 & 40 & 62 & 50 & 10 & 10 & 4 & 0 & 0 & 0 \\
never use L1 (Arabic) & 12 & 18 & 46 & 28 & 22 & 18 & 20 & 36 & 0 & 0 \\
collaborate with each other & 32 & 52 & 52 & 48 & 16 & 0 & 0 & 0 & 0 & 0 \\
enjoy communicating in L2 & 30 & 60 & 58 & 40 & 12 & 0 & 0 & 0 & 0 & 0 \\
\hline
\end{tabular}

Most of the teachers opined (strongly agree and agree) that CLT impacts communicative competence of the students in terms of enjoying communicating in L2 (94\%), collaborating with each other (92\%), communicating effectively in L2 (88\%), acquiring native-like fluency (75\%), and acquiring native-like accuracy (72\%). It means that classroom activities should have the primary role of promoting communicative language use (Brown, 2007).

On the other hand, there was discrepancy in respondents' opinions regarding the statements about acquiring native-like pronunciation, never use L1 (Arabic) in the classroom, and talk like a native speaker. Though female teachers agreed to the statements 'never use L1 (46\%) and acquiring native-like pronunciation (38\%), but a good number of female teachers disagreed to these statements (36\% and 34\%) respectively. At the same time, $30 \%$ and $28 \%$ of female teachers were not sure about the statements that CLT may impact students talk like a native speaker and acquire native-like pronunciation.

Though most of Saudi university students have instrumental motivation to learn English (Javid, Al-asmari, \& Farooq, 2012), there are still limited opportunities to practice the target language in society. Practically, they need it to pass an exam, undertake higher education, apply for a job in international organizations, or deal with business documents, etc., but it is not required for oral interaction. As such, the lack of real need to use English in social life may make it difficult for learners to be keen to acquire high proficiency. In this situation, CLT may provide a room for them to practice English to reinforce their communicative activities. Similarly, Littlewood and Liu (1996) claim that: "Students wish to have more opportunities to develop their fluency in using everyday English... however, their desire to participate in active communication in English is accompanied by an equally strong desire to have their mistakes corrected by the teacher" (p. 8) 


\subsubsection{Difficulties and Challenges in Adopting CLT in the Classroom}

Table 5. Difficulties and challenges

\begin{tabular}{|c|c|c|c|c|c|c|c|c|c|}
\hline & \multirow[t]{2}{*}{ Difficulties and Challenges } & \multicolumn{2}{|c|}{$\begin{array}{l}\text { Major } \\
\text { challenge }\end{array}$} & \multicolumn{2}{|c|}{ Challenge } & \multicolumn{2}{|c|}{$\begin{array}{c}\text { Mild } \\
\text { challenge }\end{array}$} & \multicolumn{2}{|c|}{$\begin{array}{l}\text { Not a challenges } \\
\text { at all }\end{array}$} \\
\hline & & $\mathrm{M}$ & $\mathrm{F}$ & $\mathrm{M}$ & $\mathrm{F}$ & $\mathrm{M}$ & $\mathrm{F}$ & $\mathrm{M}$ & $\mathrm{F}$ \\
\hline 1. & $\begin{array}{l}\text { Teachers have little time to develop } \\
\text { communicative activities. }\end{array}$ & 7 & 7 & 45 & 48 & 40 & 36 & 8 & 9 \\
\hline 2. & $\begin{array}{l}\text { Teachers have limited resources to develop } \\
\text { communicative material. }\end{array}$ & 22 & 35 & 45 & 28 & 28 & 26 & 5 & 11 \\
\hline 3. & Students have low-level English proficiency. & 35 & 37 & 48 & 52 & 12 & 8 & 5 & 3 \\
\hline 4. & $\begin{array}{l}\text { Students lack motivation for developing } \\
\text { communicative competence. }\end{array}$ & 11 & 17 & 62 & 28 & 23 & 45 & 4 & 10 \\
\hline 5. & $\begin{array}{l}\text { Classes are too large for the effective use of } \\
\text { CLT. }\end{array}$ & 25 & 46 & 33 & 38 & 30 & 9 & 12 & 7 \\
\hline 6. & $\begin{array}{l}\text { Lack of material for communicative } \\
\text { activities }\end{array}$ & 18 & 21 & 45 & 43 & 29 & 28 & 8 & 8 \\
\hline 7. & $\begin{array}{l}\text { CLT is unsuitable for existing examination } \\
\text { system in Saudi Arabia. }\end{array}$ & 13 & 7 & 41 & 55 & 39 & 20 & 7 & 18 \\
\hline 8. & Classrooms are not equipped with AV aids. & 21 & 63 & 52 & 18 & 22 & 14 & 5 & 5 \\
\hline 9. & $\begin{array}{l}\text { CLT lack assessment instruments in local } \\
\text { context. }\end{array}$ & 16 & 5 & 44 & 49 & 31 & 40 & 9 & 6 \\
\hline
\end{tabular}

In the fifth section of the questionnaire, teachers expressed their opinion regarding the problems and challenges they were facing in implementing CLT activities in their classroom. The major challenge highlighted by both genders was 'low-level English proficiency of students' (male: 35\% and female: 37\%). Although Saudi Arabia is spending huge budget on education and the university professors receive better salaries even as compared to the developed countries like the USA, England, Canada, Australia etc., yet the students enrolling themselves in the different faculties of Saudi universities including English lack the required English language proficiency (Shuttleworth Foundation, 2008). Much research has revealed that Arab students who take international English language proficiency tests score extremely low marks as compared to their counterparts from other nations (Rababah, 2001; Javid, Farooq, \& Gulzar, 2012). In this regard, Al-Hazmi (2006) similarly reported “...that language teaching in the Arab world is dominated by a traditional, top-down, textbook-oriented, teacher-led methodology." (p. 38).

Among other major challenges highlighted by female teachers were the lack of resources to develop material for communicative activities (35\%), large classes (46\%), and lack of AV aids (63\%). These problems were considered as challenges by male colleagues. Other challenges considered by both genders included little time for developing CLT materials, lack of materials for communicative activities, unsuitability of CLT in the exiting exams system, lack of specific materials for CLT teaching, lack of assessment instruments to assess communicative competency of the students, and lack of motivation among students. Therefore, teachers in such contexts may restrict themselves to textbook activities and procedures though they have the ability to design CLT materials. However, teachers may view this endeavour as an extra burden. Also, the classroom structure may not be supportive for conducting pair and group work and there is a limited access to AV aids in the classrooms. Moreover, large classes prohibit teachers to carry out CLT activities in their classroom. In contrast to these requirements, an English language teacher's academic and professional knowledge as well as life experience may not be rich enough to make him capable of using CLT for the purpose of teaching English in Saudi Arabia. Quite some teachers use CLT in their classroom without having a basic working knowledge of the systems of the target language try to implement CLT in their classrooms. In the same way, learners do not feel a need for using the target language in daily communication including the work place, because the majority of them use their native language. In such a situation, teachers cannot play their role as a facilitator effectively as expected. 


\subsubsection{Classroom Observation}

The researcher observed 10 classes of male teachers to triangulate the data collected through the questionnaire. The teachers had been teaching the same course (English 1) to the university students enrolled in the first semester of Preparatory Year Program. The observation points focused on various aspects of communicative language teaching. All the rooms, except one, had fixed chairs accommodating 60-70 students in each class. The following points were observed in the classroom observation.

Table 6. Classroom observation

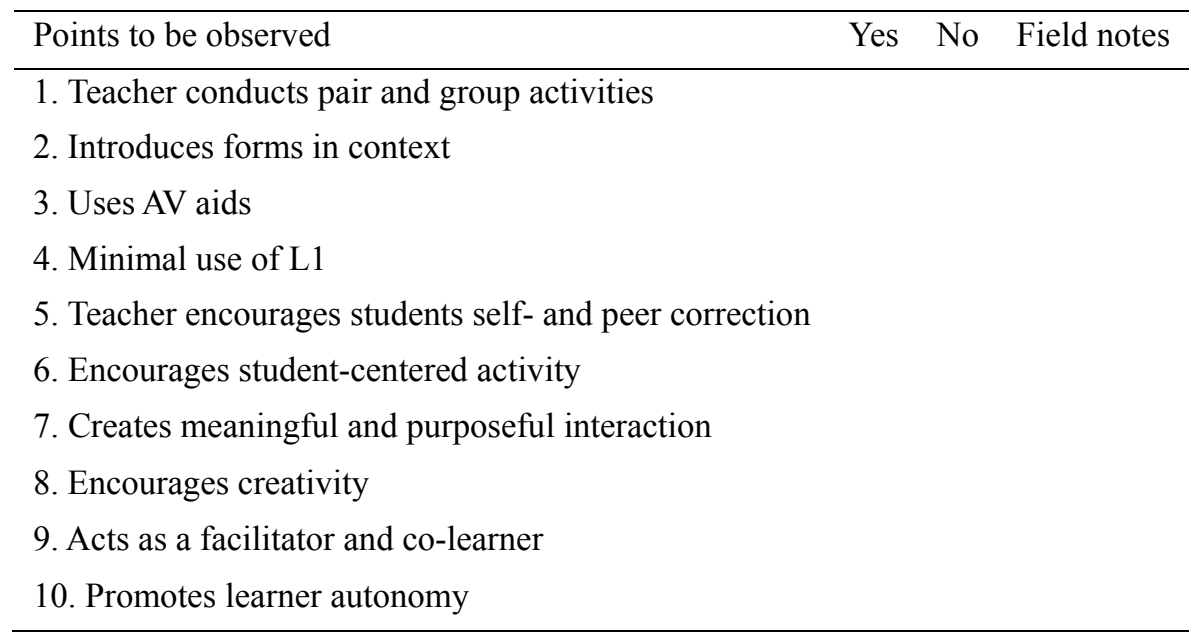

The syllabus is activity based introducing four skills and grammar in context. However, the teachers from different countries have not got CLT training so they applied their own professional skills to exploit the activities. They used the study materials available in the book and no other teaching activity was observed. Having fixed student chairs, grouping of the students was not possible. However, in one room with moveable chairs, the teacher did not attempt to conduct any group work with a reason that he does not have enough time for group work. Another reason given for not attempting group activities was that students usually start talking in Arabic instead of English. In addition, limited pair work was observed in some classes with the same reason that student when asked to discuss a point in pair, they start talking in their native language. Perhaps the students lacked the required confidence or might feel inhibited to speak English to each other so they switch over to Arabic. This also reflected their low proficiency in English which was considered as a major challenge by the teachers in the questionnaire. It was also observed that some teachers having the same native language used Arabic to explain meanings of difficult work or concepts. Accordingly, such situations hindered the process of creating a meaningful and purposeful interaction in the class, promoting learner autonomy and encouraging students for self- or peer correction. On the other hand, observations revealed that the teachers attempted to encourage creativity among students through questioning techniques and the use of $\mathrm{AV}$ aids.

\section{Conclusion}

CLT has got popularity in the last forty years or so and despite the opposing views on the appropriateness, its feasibility of implementation has been discussed in EFL context over the world. In Saudi universities, despite certain constraints, there is a considerable number of English language teachers who are aware of the CLT and are implementing it in their classroom and mostly female teachers are more interested in CLT to improve communicative competence of their students. Another aspect to improve communicative competence of the students is curriculum. Recently, most of the universities in Saudi Arabia have adopted communicative syllabus focusing on the use of language as a means of communication rather than the rules of grammar. However, CLT cannot be effectively implemented due to certain constraints like large classes, lack of AV aids, problems in conducting pair and group work, and low level of learners' proficiency in English language. The present research tried to find out the perception, practices and difficulties of implementing CLT in the classroom despite its effectiveness. As the meaningful communication provides the students with a better opportunity to enhance their communicative competence, it is recommended that:

- Teachers may prepare CLT activities, plan lessons, and create CLT environment to develop communicative competence of the students. 
- $\quad$ By adopting CLT, teachers may make real communication the focus of language learning.

- Teachers may provide opportunities to learners to develop both accuracy and fluency in a CLT environment.

- Teachers may link the different skills such as speaking, reading, and listening together, since they usually occur so in the real world.

- In a CLT environment, students may induce or discover grammar rules.

- Administration may arrange professional development courses for teachers to develop CLT environment.

- Administration may provide teachers access to resources and AV aids for effective implementation of CLT.

- $\quad$ CLT environment may motivate the students as they need to communicate in real life context.

- $\quad$ Class size may be reduced / adjusted for effective implementation of CLT.

- For effective CLT environment, assessment instruments may be developed to assess communicative competence of the students.

- Syllabus designer may re-designed language curriculum to help teachers in developing communicative competence of the students.

\section{References}

Akram, M., \& Mehmood, A. (2011). The need of communicative approach (in ELT) in teacher training program in Pakistan. Language in India, 11(5), 172-178.

Al-Hazmi, S. (2006). Writing and reflections: Perspectives of Arab EFL learners. South Asian Language Review, $X V I(2), 36-52$.

Allen, J. P. B. (1978). New development in curriculum: the notional and the structural syllabus. Paper read at the TEAL Conference, Vancouver, B.C., March 1978. Mimeo.

Andrews, S. (2003). Teacher language awareness and the professional knowledge base of the L2 teachers. Language Awareness, 12, 81-95. http://dx.doi.org/10.1080/09658410308667068

Breen, M. P., \& Candlin, C. N. (2001). The essentials of a communicative curriculum in language teaching. In D. R. Hall, \& A. Hewings (Eds.), Innovation in English language teaching: A reader (pp. 9-26). London: Routledge.

Brown, H. D. (2007). Teaching by Principles. An Interactive Approach to Language Pedagogy. New Jersey: Prentice Hall Regents.

Campbell, R., \& Wales, R. (1970). The study of language acquisition. In J. Lyons (Ed.), New horizons in linguistics. Harmondsworth: Penguin Books.

Canale, M., \& Swain, M. (1980). Theoretical bases of communicative approaches to second language teaching and testing. Applied Linguistics, 1(1), 1-47.

Candlin, C. N. (1978). Discoursal patterning and the equalising of integrative opportunity. Paper read at the conference on English as an international and intranational language, The East-West Centre, Hawaii. April 1978. Mimeo.

Celce-Murcia, M. (1991). Grammar pedagogy in second and foreign language teaching. TESOL Quarterly, 25, 459-480.

Chomsky, N. (1965). Aspects of the theory of syntax. Cambridge: MIT Press.

Creswell, J. W. (2003). Research design: Quantitative, qualitative, and mixed methods approaches (2nd ed.). Thousand Oaks, CA: Sage.

Creswell, J. W., Plano-Clark, V. L., Gutmann, M. L., \& Hanson, W. E. (2003). Advanced mixed methods research designs. In A. Tashakkori, \& C. Teddlie (Eds.), Handbook of mixed methods in social and behavioral research (pp. 209-240). Thousand Oaks, CA: Sage.

Fang, Z. (1996). A review of research on teacher beliefs and practices. Education Research, 38(1), 47-64.

Gorsuch, G. (2000). EFL educational policies and education cultures: Influences on teachers' approval of communicative activities. TESOL Quarterly, 34(4), 675-710.

Gorsuch, G. (2001). Japanese EFL Teachers' Perceptions of Communicative, Audiolingual and Yakudokuactivities: The plan versus the reality. Education Policy Analysis Archives, 9(10). Retrieved 
October 3, 2014, from http://epaa.asu/epaa/v9n10.html

Habermas, J. (1970). Introductory remarks to a theory of communicative competence. Inquiry. 13.3. Reprinted in H. P. Dreitsel (Ed.), Recent Sociology (No. 2). London: Macmillan.

Holliday, A. (1994). The house of TESEP and the communicative approach: The special needs of state English language education. ELT Journal, 48(1), 3-11.

Hymes, D. (1971). Competence and performance in linguistic theory. In R. Huxley, \& E. Ingram (Eds.), Language acquisition: Models and methods. London: Academic Press.

Hymes, D. (1972). On Communicative Competence. In J. B. Pride, \& J. Holmes (Eds.), Sociolingguistics. Harmondsworth: Penguin.

Jakobovits, L. A. (1970). Foreign language learning. Rowley, Mass.: Newbury House.

Javid, C. Z., Al-thubaiti, T. S., \& Uthman, A. (2013). Effects of English Language Proficiency on the Choice of Language Learning Strategies by Saudi English-major Undergraduates. English Language Teaching, 6(1), 35-47.

Javid, C. Z., Asmari, A. A., \& Farooq, U. (2012). Saudi Undergraduates' Motivational Orientations towards English Language Learning along Gender and University Major Lines: A Comparative Study. European Journal of Social Sciences, 27(2), 283-300. Retrieved from http://www.europeanjournalofsocialsciences.com/issues/EJSS_27_2.html

Javid, C. Z., Farooq, U., \& Gulzar, M. A. (2012). Saudi English-major undergraduates and English Teachers' perceptions regarding effective ELT in the KSA: A Comparative Study. European Journal of Scientific Research, 85(1), 55-70. Retrieved from http://www.europeanjournalofscientificresearch.com/ISSUES/EJSR_85_1.htm

Kern, R., \& Warschauer, M. (2000). Introduction: Theory and practice of network-based language teaching. In M. Warschauer, \& R. Kern (Eds.), Network-based language teaching: Concepts and Practice (pp. 1-19). New York: Cambridge University Press.

Khan, I. (2011). Role of Applied Linguistics in the Teaching of English in Saudi Arabia. International journal of English Linguistics, 1(1), 105-114.

Li, D. (1998). It's always more difficult than you plan and imagine: Teachers' perceived difficulties in introducing the communicative approach in South Korea. TESOL Quarterly, 32(4), 677-703.

Littlewood, W., \& Liu, N. F. (1996). Hong Kong students and their English. Hong Kong: Macmillan.

Luk, J. C. M., \& Lin, A. M. Y. (2007). Classroom interactions across-cultural encounters. Mahwah, NJ: Lawrence Erlbaum Associates, Inc.

Medgyes, P. (1990). Queries from a communicative teacher. In R. Rossner, \& R. Bolitho (Eds.), Currents of change in English language teaching (pp. 103-109). OUP.

Mey, J. L. (1998). Concise encyclopedia of pragmatics. Amsterdam: Elsevier.

Morrow, K. E. (1977). Techniques of evaluation for a notional syllabus. Reading: Centre for Applied Language Studies, University of Reading.

Munby, J. (1978). Communicative syllabus design. Cambridge: CUP.

Nunan, D. (1991). Language teaching methodology: A textbook for teachers. London: Prentice Hall.

Phillips, J. K. (1999). Introduction: Standards for World Languages \& mdash; One a Firm Foundation. In J. K. Phillips (Eds.), Foreign Language Standards: Linking Research, Theories, and Practices (pp. 1-14). Chicago, IL: National Textbook Company.

Rababah, G. (2001). An Investigation into the Strategic Competence of Arab Learners of English at Jordanian Universities ( $\mathrm{PhD}$ dissertation, University of Newcastle upon Tyne, UK).

Richards, J. (With Hull, J., \& Proctor, S.). (1998). New interchange (2nd ed.). Cambridge, UK: Cambridge University Press.

Richards, J. C. (2006). Communicative language teaching today. New York: Cambridge University Press.

Richards, J. C., \& Rodgers, T. (2001). Approaches and methods in language teaching (2nd ed.). New York: Cambridge University Press. 
Richards, J. C., \& Rodgers, T. S. (1987). The nature of approaches and methods in languageteaching. En Approaches and Methods in Language Teaching (pp. 14-30). ReinoUnido: Cambridge University Press.

Richards, J., \& Sandy, C. (2008). Passages (2nd ed.). Cambridge, UK: Cambridge University Press.

Richards, J., Platt, J., \& Platt, H. (1992). Dictionary of language teaching \& applied linguistics. London: Longman.

Savignon, S. (1983). Communicative competence: Theory and classroom practice. Reading, MA: Addyson-Wesley.

Savignon, S. J. (1972). Communicative competence: an experiment in foreign language teaching. Philadelphia: Center for Curriculum Development.

Savignon, S. J. (Ed.). (2002). Interpreting communicative language teaching: Contexts and concerns in teacher education. New Haven: Yale University Press.

Stern, H. H. (1978). The formal-functional distinction in language pedagogy: A conceptual clarification. Paper read at the $5^{\text {th }}$ AILA Congress, Montreal, August. Mimeo.

Taguchi, N. (2002). Implementing oral communication classes in upper secondary schools: A case study. The Language Teacher Online. Retrieved September 15, 2014, from http://www.jalt-publications.org/tlt/articles/2002/12/taguchi

Tashakkori, A., \& Teddlie, C. (1998). Mixed methodology: Combining qualitative and quantitative approaches. Thousand Oaks, CA: Sage.

Van Ek, J., (Ed.). (1975). Systems development in adult language learning: The threshold level in a European unit credit system for modern language learning by adults. Strasbourg: Council of Europe.

Vasilopoulos, G. (2008). Adapting communicative language instruction in Korean Universities. The Internet TESOL Journal, 14, 8.

Wang, R. (1990). Focusing on oral communicative competence. English Teaching Forum, 28, 36-38.

Wei, L. (2011). CLT in EFL context: not a universal medicine. IDIOM, 41, 3.

Wenjie, C. (2009). Using CLT to improve speaking ability of Chinese non-English major students. (M.A. thesis, University of Wisconsin Platteville). Retrieved September 18, 2014, from $\mathrm{http} / /$ minds.wisconsin.edu/bitstream/handle

Wilkins, D. (1976). Notional syllabuses. Oxford: Oxford University Press.

Xia, J. (2010). Communicative Language Teaching in Vocabulary Teaching and Learning in a Swedish Comprehensive Class. Retrieved August 20, 2014, from http://hkr.diva-portal.org/smash/get/diva2:328283/FULLTEXT01.pdf

\section{Copyrights}

Copyright for this article is retained by the author(s), with first publication rights granted to the journal.

This is an open-access article distributed under the terms and conditions of the Creative Commons Attribution license (http://creativecommons.org/licenses/by/3.0/). 